\title{
PENGARUH MOTIVASI DAN KOMITMEN TERHADAP BUDAYA ORGANISASI DAN KINERJA PEGAWAI PADA KANTOR DINAS KEPENDUDUKAN DAN PENCATATAN SIPIL KABUPATEN JEMBER
}

\section{THE EFFECT OF MOTIVATION AND COMMITMENT TO ORGANIZATIONAL CULTURE AND EMPLOYEE PERFORMANCE IN THE OFFICE OF JEMBER DISTRICT AND CIVIL REGISTRATION OFFICE}

\author{
Mochamad Rizal Rofik Efendy ${ }^{1}$, Toni Herlambang ${ }^{2}$, Yusron Rozaid ${ }^{3}$ \\ Fakultas Ekonomi Universitas Muhammadiyah Jember ${ }^{123}$ \\ Email:toniherlambang@unmuhjember.ac.id dan yusronrozzaid@gmail.com
}

\begin{abstract}
ABSTRAK
Penelitian ini bertujuan untuk mengetahui pengaruh motivasi dan komitmen terhadap budaya organisasi dan kinerja pegawai pada Dinas kependudukan Dan Pencatatan Sipil Kabupaten Jember. Responden dalam penelitian ini adalah seluruh pegawai baik yang berstatus Pegawai Negeri Sipil maupun Pegawai Kontrak. Data yang digunakan dalam penelitian ini adalah data primer dan data sekunder. Analisis data yang digunakan dalam penelitian ini adalah analisis path yang merupakan pengembangan dari analisis regresi dengan menggunakan bantuan SPSS versi 17. Hasil penelitian ini dapat disimpulkan bahwa dimensi dari setiap variabel dari setiap pengujian hipotesis memiliki hasil positif baik secara langsung antara variabel terikat terhadap variabel bebas atau melalui variabel perantara. Hal ini menunjukkan bahwa variabel-variabel bebas memiliki pengaruh yang sigifikan terhadap variabel perantara dan variabel terikat.
\end{abstract}

Kata Kunci: motivasi, komitmen, budaya organisasi dan kinerja.

\begin{abstract}
This research aims to know the effect of motivation and Commitment on Culturing Organization and The employees Performance on Populations and Registry office of Jember). The respondent of this research are all of the staffs on Populations and Registry office either Government Civil Servant staff or freelance staff. Primary and Secondary data were used in this research. The data Analysis is used path Analysis which is development of regression analysis helping with SPSS version of 17. The result of this research showed that dimension from every variable of every hypotesis treatment has showed a positive result between dependent and independent variable either directly or correlation variable. In this scase, the research showed that Independent variable has a significant effect on correlation variable and dependent variable.
\end{abstract}

Keywords: motivation, commitment, culturing organization and performance. 


\section{PENDAHULUAN}

Sumber daya manusia adalah faktor sentral dalam organisasi. Apapun bentuk serta tujuanya, organisasi di buat berdasarkan berbagai visi untuk kepentingan manusia dan dalam pelaksanaan misinya dikelola dan diurus oleh manusia. Jadi manusia merupakan faktor strategis dalam semua kegiatan institusi atau organisasi. Sumber daya manusia memiliki peran yang sangat penting dalam proses pencapaian tujuan organisasi yang ada. Untuk itu sumber daya manusia perlu di kembangkan dan diperhatikan agar kualitas sumber daya manusia tersebut dapat di tingkatkan, sehingga berdampak pada meningkatnya kinerja organisasi dimana sumber daya manusia tersebut berada (Dudokia, 2014).

Keberhasilan suatu institusi atau organisasi di tentukan oleh dua faktor utama yakni sumber daya manusia dan fasilitas atau sarana pendukung. Akan tetapi secanggih dan selengkap apapun fasilitas atau sarana pendukung yang dimiliki suatu organisasi tanpa adanya sumber daya manusia yang memadai baik jumlah (kuantitas) maupun kemampuannya, maka organisasi tersebut akan sulit mewujudkan visi, misi, dan tujuan organisasi (Notoatmodjo, 2009). Berbicara sumber daya manusia bila di kaitkan dengan organisasi, sangat erat kaitannya dengan pegawai atau tenaga kerja. Pegawai yang profesional dan berkualitas akan membentuk prestasi kerja yang tinggi, baik secara individu maupun kelompok yang kemudian berdampak pada efektivitas organisasi secara keseluruhan. Oleh karena itu, produktivitas kerja anggota organisasi yang tinggi sangat diperlukan dalam orgnisasi, karena produktivitas kerja pegawai sangat mempengaruhi kinerja organisasi.

Persoalannya adalah bagaimana dapat menciptakan sumber daya manusia yang produktif yang dapat menghasilkan prestasi kerja yang optimal sehingga tujuan organisasi dapat tercapai. Berbicara tentang prestasi kerja pegawai tidak akan terlepas dengan adanya faktor-faktor yang dapat mempengaruhi kinerja seseorang. Mengingat permasalahan sangat kompleks terjadi, maka pihak-pihak yang terlibat dalam organisasi harus cermat dalam mengawasi sumber daya yang ada. Budaya organisasi adalah suatu faktor yang mempengaruhi tendensi anggota untuk tetap bersama organisasi, mencari serta menjaga loyalitasnya. budaya organisasi akan membentuk nilai dan standar yang menuntun perilaku organisasi sehingga kondisi tersebut dapat menentukan arah dari seluruh tujuan organisasi. Selain itu budaya organisasi juga merupakan nilai-nilai 
bersama dan kepercayaan yang diberikan oleh anggota kepada organisasi dan menyaediakan para anggota dengan aturan-aturan dalam berprilaku (Robbins, 2002). Suatu budaya organisasi yang kuat memperlihatkan kesepakatan yang tinggi dikalangan anggota mengenai tujuan organisasi itu yang ditandai oleh nilai-nilai inti yang dipegang kokoh dan disepakati secara luas. Sehingga kuat lemahnya budaya suatu organisasi sangat bergantung bagaimana anggota menghayati dan mengamalkan nilai-nilai yang terkandung dalam budaya organisasi tersebut. Budaya yang kuat tentunya akan dapat menciptakan dan memperkuat komitmen karyawan terhadap organisasi.

Selain budaya organisasi, faktor lain yang perlu di perhatikan dalam mencapai kinerja organisasi yang baik adalah komitmen dari para pegawai. Komitmen organisasi adalah tingkat identifikasi dan keterlibatan individu dengan suatu organisasi sehingga individu tidak menginginkan untuk meninggalkan organisasi tersebut. Dengan kata lain komitmen merupakan suatu pengikat seseorang dengan suatu institusi. Kedua faktor tersebut merupakan faktor yang dapat mempengaruhi kinerja secara langsung ataupun melalui faktor yang lain yaitu dalam hal ini adalah adanya motivasi. Motivasi adalah faktor yang terdapat dalam diri seseorang yang dapat mengarahkan perilakunya untuk memenuhi tujuan tertentu (Rivai dan Sagala, 2009). Dalam hal ini adanya motivasi dapat mendorong seseorang sehingga dapat berbuat sesuatu, dengan demikian motivasi dapat diartikan sebagai motor yang dapat menimbulkan energi dalam diri seseorang untuk berbuat sesuatu.

Komitmen dan motivasi yang kuat akan mencerminkan besarnya tanggung jawab seseorang terhadap tugas-tugas yang diberikan kepadanya, hal ini mendorong gairah kerja, semangat kerja, dan terwujudnya tujuan organisasi. Komitmen dan motivasi dari pegawai juga akan menunjukkan bahwa organisasi dapat memelihara serta menjaga loyalitas dan kualitas pegawainya, dari Komitmen dan motivasi ini juga dapat diketahui nilai kinerja dari para pegawainya. Demikian pula halnya dengan Kantor Dinas Kependudukan Dan Pencatatan Sipil Kabupaten Jember.

Pada dasarnya kinerja seorang pegawai berbeda-beda satu sama lain. Hal ini dikarenakan setiap pegawai mempunyai tingkat kemampuan yang berbeda-beda dalam mengerjakan tugas pekerjaannya. Kinerja pegawai juga dapat dilihat pada Dinas Kependudukan dan Pencatatan Sipil Kabupaten Jember. Dinas kependudukan dan Pencatatan Sipil Kabupaten Jember merupakan unsur pelaksana otonomi daerah di 
bidang Kependudukan dan Pencatatan Sipil. Dinas Kependudukan dan Pencatatan Sipil ini mempunyai tugas pokok dan fungsi meliputi Administrasi Kependudukan, Mobilitas Penduduk, dan Pencatatan Sipil.

Pelaksanaan tugas dan fungsi dari Dinas Kependudukan dan Pencatatan Sipil Kabupaten Jember harus sesuai dengan tertib administrasi. Tugas dan fungsi Dinas Kependudukan dan Pencatatan Sipil Kabupaten Jember tertuang dalam Peraturan Bupati Jember Nomor 2 Tahun 2012 tentang Penjabaran Tugas dan Fungsi Dinas Kependudukan dan Pencatatan Sipil Kabupaten Jember (Sumber: Bucklet Persyaratan Pengurusan Dokumen Pencatatan Sipil). Dari latar belakang dan fenomena yang ada di Kantor Dinas Kependudukan Dan Pencatatan Sipil Kabupaten Jember yang dikaitkan dengan masalah komitmen dan motivasi dalam bekerja, peneliti menduga terdapat hubungan antara komitmen dan motivasi terhadap kinerja pegawainya.

Berdasarkan latar belakang diatas terdapat perumusan masalah yang dapat diambil adalah:

a. Apakah motivasi dan komitmen organisasi berpengaruh signifikan terhadap kinerja pegawai pada Dinas Kependudukan dan Pencatatan Sipil Kabupaten Jember?

b. Apakah motivasi dan komitmen organisasi berpengaruh signifikan terhadap budaya organisasi Dinas Kependudukan dan Pencatatan Sipil Kabupaten Jember?

c. Apakah budaya organisasi berpengaruh signifikan terhadap kinerja pegawai pada Dinas Kependudukan dan Pencatatan Sipil Kabupaten Jember?

Berdasarkan uraian pada perumusan masalah diatas, maka tujuan penulisan Tesis ini adalah:

a. Untuk menganalisis motivasi berpengaruh signifikan atau tidak terhadap budaya organisasi pada Dinas Kependudukan dan Pencatatan Sipil Kabupaten Jember.

b. Untuk menganalisis komitmen organisasi berpengaruh signifikan atau tidak terhadap budaya organisasi pada Dinas Kependudukan dan Pencatatan Sipil Kabupaten Jember.

c. Untuk menganalisis motivasi berpengaruh signifikan atau tidak terhadap kinerja pegawai Dinas Kependudukan dan Pencatatan Sipil Kabupaten Jember. 
d. Untuk menganalisis komitmen organisasi berpangaruh signifikan atau tidak terhadap kinerja pegawai Dinas Kependudukan dan Pencatatan Sipil Kabupaten Jember.

e. Untuk menganalisis budaya organisasi berpengaruh signifikan atau tidak terhadap kinerja pegawai Dinas Kependudukan dan Pencatatan Sipil Kabupaten Jember.

\section{TINJAUAN PUSTAKA}

\section{Budaya Organisasi}

Menurut Robbins (2002:246) setiap organisasi mempunyai suatu budaya dan bergantung pada kekuatannya sehingga budaya dapat mempunyai pengaruh yang bermakna pada sikap dan perilaku anggota-anggotanya dalam organisasi. Menurut Mangkunegara (2005:113) budaya organisasi didefinisikan sebagai perangkat asumsi atau sistem keyakinan, nilai-nilai dan norma-norma yang dikembangkan dalam organisasi yang dijadikan pedoman tingkah laku bagi anggota-anggotanya untuk mengatasi masalah adaptasi eksternal dan integrasi internal. Dalam budaya mengandung apa yang boleh dilakukan dan yang tidak boleh dilakukan sehingga dapat dikatakan sebagai suatu pedoman yang dipakai untuk menjalankan aktivitas dalam organisasi.

\section{Komitmen Organisasi}

Menurut Sterrs dan Porter dalam Supriyono (2006) berpendapat bahwa komitmen organisasi merupakan kondisi dimana karyawan sangat tertarik terhadap tujuan, nilainilai dan sasaran organisasi. Komitmen terhadap organisasi artinya lebih dari sekedar keanggotaan formal karena meliputi sikap menyukai organisasi dan kesediaan untuk mengusahakan tingkat upaya yang tinggi bagi kepentingan organisasi demi tercapainya tujuan. Berdasarkan definisi dalam komitmen mencakup loyalitas terhadap organisasi, keterlibatan dalam pekerjaan dan identifikasi terhadap nilai-nilai dan tujuan organisasi.

\section{Motivasi}

Perbedaan yang sering terjadi antar karyawan dalam bekerja biasanya didorong oleh keinginan atau adanya motivasi tertentu. Keadaan seperti inilah menurut para manajer untuk dapat memainkan peranya itu bagaimana menciptakan, merangsang kelompok karyawan yang berlainan guna menciptakan kinerja yang maksimal. Motivasi adalah faktor-faktor yang ada dalam diri seseoarang yang menggerakkan dan mengarahkan perilakunya untuk memenuhi tujuan tertentu. Proses timbulnya motivasi 
seseorang ini merupakan gabungan dari konsep kebutuhan, tujuan dan imbalan. Rivai dan Sagala (2009:23) menyatakan bahwa motivasi adalah serangkaian sikap dan nilai-nilai yang mempengaruhi individu untuk mencapai hal yang spesifik sesuai dengan tujuan individu. Sikap dan nilai-nilai tersebut merupakan sesuatu yang invisible yang memberikan kekuatan untuk mendorong individu bertingkah laku dalam mencapai tujuan. Hal ini akan meningkatkan produktivitas kerja karyawan sehingga berpengaruh pada pencapaian tujuan perusahaan. Ada tiga faktor dalam sumber motivasi yakni antara lain: (a) kemungkinan untuk berkembang, (b) jenis pekerjaan, (c) apakah mereka dapat merasa bangga menjadi bagian dari perusahaan tempat mereka bekerja.

\section{Kinerja}

Kinerja Sumber Daya Manusia (SDM) merupakan istilah yang berasal dari kata job performance atau actual performance (prestasi kerja atau prestasi sesugguhnya yang dicapai seseorang). Menurut Mangkunegara (2005:67) kinerja merupakan hasil kerja secara kualitas dan kuantitas yang dicapai oleh seorang pegawai dalam melaksanakan tugasnya sesuai dengan tanggung jawab yang diberikan kepadanya. Sedangkan menurut Wibowo (2010:22) kinerja karyawan adalah hasil kinerja karyawan dilihat dari aspek kualitas, kuantitas dan waktu kerja sama untuk mencapai tujuan yang sudah ditetapkan oleh organisasi.

Berdasarkan beberapa pengertian tersebut dapat disimpulkan bahwa kinerja adalah hasil kerja secara kualitas dan kuantitas yang dicapai seorang karyawan berdasarkan kriteria yang berlaku untuk pekerjaan tersebut dalam kurun waktu yang telah ditetapkan, artinya bahwa bila aktivitas seseorang dalam organisasi dapat mencapai maksimal sesuai dengan standar yang berlaku maka dapat dikatakan kinerjanya baik dan sebaliknya apabila tidak tercapai maka berarti perusahaan mimiliki kinerja yang buruk. Hasil kerja yang dicapai seorang karyawan dalam melakukan suatu pekerjaan dapat dievaluasi tingkat kinerja pegawainya dan kinerjanya dapat ditentukan dengan pencapaian target selama periode waktu yang dicapai organisasi. 


\section{Kerangka konseptual}

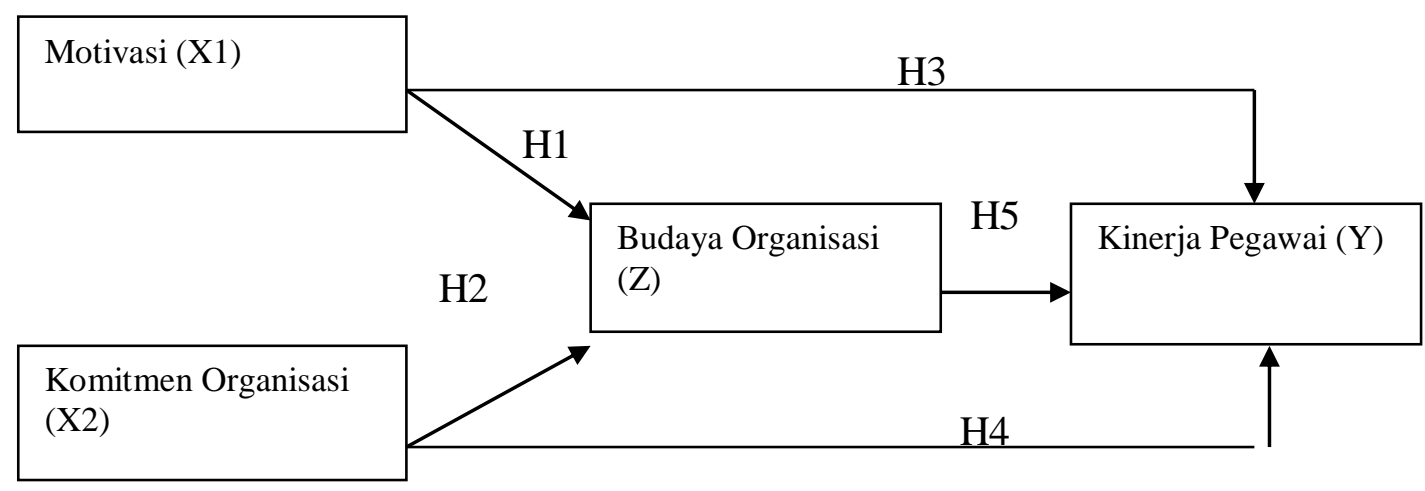

Gambar 1. Kerangka Konseptual Model Analisis Jalur

Sumber: data diolah, 2015

\section{Hipotesis Penelitian}

Berdasarkan rumusan masalah, tujuan penelitian dan kerangka konseptual di atas maka hipotesis yang diajukan dalam penelitian ini adalah sebagai berikut:

H1. Motivasi berpengaruh positif dan signifikan terhadap budaya organisasi pada Dinas Kependudukan Dan Pencatatan Sipil Kabupaten Jember.

H2. Komitmen organisasi berpengaruh positif dan signifikan terhadap budaya organisasi pada Dinas Kependudukan Dan Pencatatan Sipil Kabupaten Jember.

H3. Motivasi berpengaruh positif dan signifikan terhadap kinerja pegawai pada Dinas Kependudukan Dan Pencatatan Sipil Kabupaten Jember.

H4 Komitmen organisasi berpengaruh positif dan signifikan terhadap kinerja pegawai pada Dinas Kependudukan Dan Pencatatan Sipil Kabupaten Jember.

H5. Budaya organisasi berpengaruh positif dan signifikan terhadap kinerja pegawai pada Dinas Kependudukan Dan Pencatatan Sipil Kabupaten Jember.

\section{METODE PENELITIAN}

\section{Rancangan Penelitian}

Krakteristik dari penelitian ini adalah explanatory research yaitu penelitian yang menjelaskan hubungan kausal dan menguji keterkaitan antara beberapa variabel melalui pengujian hipotesis atau penelitian penjelasan. Dalam penelitian ini dilakukan pengujian hipotesis untuk mengetahui asosiasi antar variabel yang diuji. Perusahaan atau instansi yang menjadi objek penelitian adalah Dinas Kependudukan dan Pencatatan Sipil 
Kabupaten Jember. Penelitian ini difokuskan pada pengaruh variabel budaya organisasi, komitmen organisasi, motivasi dan kinerja pegawai

\section{Populasi Dan Sampel}

Populasi dalam penelitian ini adalah seluruh pegawai pada Dinas Kependudukan dan Pencatatan Sipil Kabupaten Jember. Pengambilan sampel didasarkan atas jumlah pupulasi yang ada pada instansi, hal ini dimaksudkan untuk memudahkan peneliti dalam mengambil kesimpulan. Sampel yang diambil dalam penelitian ini adalah seluruh pegawai pada Dinas Kependudukan dan Pencatatan Sipil Kabupaten Jember baik yang berstatus Pegawai Negeri ataupun Pegawai Kontrak. Karena dalam hal ini pegawai yang ada pada suatu instansi objek penelitian berjumlah 54 pegawai dimana jumlah pegawai yang berstatus Pegawai Negeri berjumlah 37 pegawai sedangkan berstatus Pegawai Kontrak berjumlah 17 pegawai. Semakin besar jumlah sampel (semakin mendekati populasi) maka semakin kecil peluang kesalahan generalisasi dan semakin kecil jumlah sampel (menjauhi jumlah populasi) maka semakin besar peluang kesalahan generalisasi (Tantowi, 2014). Sehingga dalam penelitian ini sampel yang dilakukan pada penelitian ini adalah 54 pegawai baik yang berstatus pegawai negeri sipil maupun pegawai kontrak pada Dinas Kependudukan Dan Pencatatan Sipil Kabupaten Jember.

\section{Uji Validitas dan Uji Relibilitas}

lnstrumen yang valid berarti instrument itu dapat mengukur mengukur apa saja yang seharusnya diukur (Sugiyono, 2002:172). Uji validitas data bertujuan untuk mengetahui kevalidan data yang diperoleh dari penyebaran kuesioner. Uji validitas dapat dilakukan dengan menghitung korelasi antara masing-masing pertanyaan dengan skor total pengamatan. Uji validitas dalam penelitian ini dilakukan dengan metode Pearson Product Moment. Dalam pengujian ini digunakan asumsi bahwa nilai korelasi dengan metode Pearson Product Moment tinggi maka dikatakan valid. Reliabilitas adalah indeks yang menunjukkan sejauh mana suatu alat pengukur dapat menunjukkan dipercaya atau tidak. Uji dilakukan setelah uji validitas dan dilakukan pada pernyataan yang sudah memiliki validitas. Pengujian reliabilitas. dalam penelitian ini dilakukan dengan menghitung Cronbach Alpha dari masing-masing item pertanyaan dalam suatu variabel (Nasution, 2001:23). 


\section{Analisis Jalur}

Analisis jalur merupakan bagian dari analisis regresi yang digunakan untuk menganalisis hubungan antar variabel, dimana variabel-variabel bebas mempengaruhi variabel terikat baik secara langsung maupun tidak langsung melalui satu atau lebih perantara (Sarwono, 2006:147). Untuk menguji pengaruh variabel intervening digunakan metode analisis jalur (path analysis). Analisis jalur merupakan perluasan dari analisis regresi linier berganda, atau analisis jalur adalah penggunaan analisis regresi untuk menaksir hubungan kausalitas antara variabel (model casual) yang telah ditetapkan sebelumnya. Analisis jalur sendiri tidak dapat menentukan hubungan sebab akibat dan juga tidak dapat digunakan sebagai substitusi bagi peneliti untuk melihat hubungan kausalitas antar variabel. Hubungan kausalitas antar variabel telah dibentuk dengan model bcrdasarkan landasan teori. Analisis jalur hanya menentukan pola hubungan antara tiga atau lebih variabel.

\section{HASIL DAN PEMBAHASAN}

\section{Hasil Uji Validitas dan Uji Reliabilitas}

Hasil perhitungan menunjukkan bahwa semua variabel pertanyaan yang digunakan dalam kuisioner adilah data yang valid, yang ditunjukkan dengan nilai Pearson Correlation lebih dari nilai $r$ tabel yaitu 0.361 dengan tingkat alpha (a) sebesar 0.05 dan $n$ (sampel) = 30. Sedangkan untuk Sig. (2-Tailed) menghasilkan nilai $<0.05$ yang berarti nilai tersebut dapat dikatakan valid. Jadi semua item pertanyaan pada variabel-variabel ini dinyatakan valid. Berdasarkan hasil uji realibilitas dapat diketahui bahwa seluruh variabel yangdigunakan adalah reliable, yaitu dilihat dari nilai Cronbach Alpha yang semuanya di atas 0,8 dan nilai Item Total Correlation yang bernilai > 0,361 (nilai $\mathrm{r}$ tabel).

\section{Analisis Jalur}

Analisis jalur ini digunakan untuk mengetahui pengaruh secara langsung maupun tidak langsung dari variabel bebas terhadap variabel terikat. Analisis jalur ini dilakukan dengan menggunakan analisis regresi linear, yang diolah dengan menggunakan software SPSS 17. Berikut ini adalah hasil pengolahan dari analisis jalur. 
Tabel 1. Pengolahan Dari Analisis Jalur

\begin{tabular}{|c|c|c|c|c|c|}
\hline Model & $\begin{array}{l}\text { Koefisien } \\
\text { Inlwer }\end{array}$ & $\mathrm{T}$ & $\operatorname{sig}$ & $\mathrm{F}$ & R Square \\
\hline \multicolumn{6}{|l|}{ Persamaan 1} \\
\hline $\mathrm{X},\left(\beta \mathrm{X}_{1} \mathrm{Z}\right)$ & 0.573 & 3.429 & 0.002 & \multirow{2}{*}{77.409} & \multirow{2}{*}{0.851} \\
\hline $\mathrm{X}_{2}\left(\beta \mathrm{X}_{2} \mathrm{Z}\right)$ & 0.374 & 2.240 & 0.033 & & \\
\hline \multicolumn{6}{|l|}{ Persamaan 2} \\
\hline $\mathrm{X},\left(\beta \mathrm{X}_{2} \mathrm{Y}\right)$ & 0.732 & 3.084 & 0.005 & \multirow{3}{*}{34.426} & \multirow{3}{*}{0.799} \\
\hline $\mathrm{X}_{2}\left(\beta \mathrm{X}_{2} \mathrm{Y}\right)$ & 0.171 & C.794 & 0.435 & & \\
\hline $\mathrm{Z}(\beta \mathrm{ZY})$ & 0.006 & 0.027 & 0.979 & & \\
\hline
\end{tabular}

Sumber: Data Primer Diolah, 2015.

Dari hasil analisis jalur di atas niaka dapat diketahui pada Persamaan 1 yaitu $Z=\beta X 1 Z+\beta X 2 Z+$ el. adalah secara simultan Motivasi (X1) dan Komitmen Organisasi (X2) berpengaruh positif dan signifikan terhadap Budaya Organisai (Z). besarnya pengaruh tersebut adalah 0.851 atau $85 \%$, artinya kontribusi dari variabel Motivasi (X1) dan Komitmen Organsasi (X2) terhadap Budaya Organisasi (Z) sebesar $85 \%$, sedangkan besarnya pengaruh variabel lain di luar model ini diketahui dari 1-R Square atau 1-0.851 - 0.149. Dengan demikian, variabel diluar model ini sebesar 0.149 atau $15 \%$. Model simultan ini terjadi secara signifikan yang ditunjukkan pada probability F sebesar 77.409 lebih besar dari nilai F tabel (3.197), yang didapat dari jumlah variabel-1 atau 4-1=3 dan jumlah kasus-4 atau 21-4=17. Artinya terdapat hubungan linear antara Motivasi (X1) dan Komitmen Organisasi (X2) terhadap Budaya Organisasi (Z). Setelah itu dilakukan pengujian signifikansi. secara parsial pada setiap variabel individu. Hasil pengujian menunjukkan bahwa X2 signifikan terhadap Z, yaitu dengan nilai t hitung sebesar 3.429 lebih besar dari t tabel (1.729), t tabel di lihat dengan mengetahui Derajat Kebebasan (DK) yaitu 21-2=19, dengan tingkat alpha $(\mathrm{a})=5 \%$. Sedangkan X2 menunjukkan situasi yang signifikan terhadap Z, yaitu dengan nilai t hitung sebesar 2.240 lebih besar dan $t$ tabel (-1.729). Artinya, secara parsial Motivasi (X1) dan Komitmen Organisasi $\left(\mathrm{X}_{2}\right)$ berperngaruh terhadap variabel Budaya Organisasi (Z).

Dari angka koefisien jalur dapat diketahui bahwa Motivasi $\left(\mathrm{X}_{1}\right)$ berpengaruh positif dan signifikan terhadap Budaya Organisasi (Z) sebesar 0.573 atau 57\% . Dengan demikian tinggi rendahnya pengaruh Motivasi $\left(\mathrm{X}_{1}\right)$ secara langsung terhadap Budaya Organisasi (Z) sebesar 57\% sedangkan sisanya $43 \%$ dipengaruhi oleh variabel lain 
diluar model. Secara parsial dapat diketahui Juga bahwa Komitmen Organisasi (X2) berpengaruh positif dan signifikan terhadap Budaya Organisasi (Z) sebesar 0.374 atau $37 \%$, berarti Komitmen Organisasi mempengaruhi secara langsung terhadap Budaya Organisasi (Z) sebesar 37\%, sedangkan 63\% sisanya dipengaruhi oleh variabel di luar model.

Dari Persamaan 2, yahu $Y=\beta X 1 Y+\beta X 2 Y+\beta Z Y+$ e2. secara simultan pengaruh Motivasi $\left(\mathrm{X}_{1}\right)$, Komitmen Organisasi $\left(\mathrm{X}_{2}\right)$, dan Budaya Organisasi $(\mathrm{Z})$ terhadap Kinerja (Y) adalah sebesar 0.799 atau dapat dibulatkan menjadi 80\%, sisanya $20 \%$ dipengaruhi o'eh variabel di luar model.Besarnya variabel lain di luar model ini diketahui dari 1-R Square atau 1-0.799 =0.201. Dengan demikian, variabel diluar model ini sebesar $20 \%$. pembulatan dari $20.1 \%$.

Variabel-variabel $\mathrm{X}_{1}, \mathrm{X}_{2}, \mathrm{Z}$ juga berpegaruh signifikan dilihat dari probabilitas F sebesar 34.426 lebih besar dari nilai $F$ tabel (3.197), yang didapat dari jumlah variabel-1 atau 4-1=3 dan jumlah kasus-4 atau 21-4=17. Artinya terdapat hubungan linear antara Motivasi $\left(\mathrm{X}_{1}\right)$, Komitmen Organisasi $\left(\mathrm{X}_{2}\right)$, dan Budaya Organisasi $(\mathrm{Z})$ terhadap Kinerja (Y). Setelah model simultan dilakukan maka dilakukan pada model parsial. Hubungan secara parsial variabel Motivasi $\left(\mathrm{X}_{1}\right)$ terhadap variabel Kinerja $(\mathrm{Y})$ adalah sebesar 0.732, hubungan parsial variabel Komitmen Organisasi $\left(\mathrm{X}_{2}\right)$ terhadap Kinerja (Y) adalah sebesar 0.171, dan hubungan parsial antara variabel Budaya Organisasi (Z) dengan Kinerja (Y) adalah sebesar 0.006, artinya variabel Motivasi $\left(\mathrm{X}_{1}\right)$, Komitmen Organisasi $\left(\mathrm{X}_{2}\right)$, dan variabel Budaya Organisasi $(\mathrm{Z})$, mempunyai pengaruh positif dan signifikan terhadap variabel Kinerja (Y) yang merupakan variabel terikat.

\section{KESIMPULAN DAN SARAN}

\section{Kesimpulan}

Berdasarkan hasil pengujian hipotesis diatas mengenai pengaruh Motivasi (X1) dan Komitmen Organisasi (X2) terhadap Budaya Organisasi (Z) dan Kinerja Karyawan (Y) pada Dinas Kependudukan Dan Pencatatan Sipil Kabupaten Jember. Ada lima hipotesis yang menyatakan kelima hipotesis tersebut dapat diterima dan berpengaruh positif dan signifikan terhadap masing-masing variable yang ada pada model jalur hipotesis. Berikut ini adalahkesimpulan dari kelima hipotesis tersebut. 
a. Motivasi (X1) berpengaruh positif dan signifikan terhadap Budaya Organisasi (Z) pada Dinas Kependudukan Dan Pencatatan Sipil Kabupaten Jember dengan nilai signifikan 11.445 , pada tingkat alpha $(\alpha)=5 \%$ pada pengujian hipotesis atau uji signifikansi. Hipotesis ini dikatakan signifikan karena nilai t hitung (11.445) lebih besar dari nilai t table (-1.729). Pengaruh positif tersebut juga ditunjukkan dengan angka koefisien jalur yang menunjukkan besarnya pengaruh variabel Motivasi (X1) terhadap Budaya Organisasi (Z) sebesar 0,573 atau 57 \%.

b. Komitmen Organisasi (X2) berpengaruh positif dan signifikan terhadap Budaya Organisasi (Z) pada Dinas Kependudukan Dan Pencatatan Sipil Kabupaten Jember dengan nilai signifikan 10,166, pada tingkat alpha $(\alpha)=5 \%$ pada pengujian hipotesis atau uji signifikansi. Hipotesis ini dikatakan signifikan karena nilai t hitung $(10,166)$ lebih besar dari nilai t table (-1.729). Pengaruh positif tersebut juga ditunjukkan dengan angka koefisien jalur yang menunjukkan besarnya pengaruh variable Komitmen Organisasi (X2) terhadap Budaya Organisasi (Z) sebesar 0,374 atau $37 \%$.

c. Motivasi (X1) berpengaruh positif dan signifikan terhadap Kinerja Pegawai (Y) pada Dinas Kependudukan Dan Pencatatan Sipil Kabupaten Jember dengan nilai signifikan 10,335, pada tingkat alpha $(\alpha)=5 \%$ pada pengujian hipotesis atau uji signifikansi. Hipotesis ini dikatakan signifikan karena nilai t hitung $(10,335)$ lebih besar dari nilai t table (-1.729). Pengaruh positif tersebut juga ditunjukkan dengan angka koefisien jalur yang menunjukkan besarnya pengaruh variabel Motivasi (X1) terhadap Kinerja Pegawai (Y) sebesar 0,732 atau $73 \%$.

d. Komitmen Organisasi (X2) berpengaruh positif dan signifikan terhadap Kinerja Pegawai (Y) pada Dinas Kependudukan Dan Pencatatan Sipil Kabupaten Jember dengan nilai signifikan 7,936, pada tingkat alpha $(\alpha)=5 \%$ pada pengujian hipotesis atau uji signifikansi. Hipotesis ini dikatakan signifikan karena nilai t hitung $(7,936)$ lebih besar dari nilai t tabel (-1.729). Pengaruh positif tersebut juga ditunjukkan dengan angka koefisien jalur yang menunjukkan besarnya pengaruh variabel Komitmen Organisasi (X2) terhadap Kinerja Pegawai (Y) sebesar 0,171 atau $37 \%$.

e. Budaya Organisasi $(\mathrm{Z})$ berpengaruh positif dan signifikan terhadap Kinerja Pegawai (Y) pada Dinas Kependudukan Dan Pencatatan Sipil Kabupaten Jember 
dengan nilai signifikan 7,637, pada tingkat alpha $(\alpha)=5 \%$ pada pengujian hipotesis atau uji signifikansi. Hipotesis ini dikatakan signifikan karena nilai t hitung $(7,637)$ lebih besar dari nilai t table $(-1.729)$. Pengaruh positif tersebut juga ditunjukkan dengan angka koefisien jalur yang menunjukkan besarnya pengaruh variabel Budaya Organisasi (Z) terhadap Kinerja Pegawai (Y) sebesar 0,006 atau $0,6 \%$.

\section{Saran}

Dari hasil penelitian diatas, penulis mendapatkan beberapa hal yang masih ada kemungkinan untuk dapat ditingkatkan lagi oleh pihak instansi yaitu Dinas Kependudukan Dan Pencatatan Sipil Kabupaten Jember. beikut ini adalah beberapa saran dari penelitiyang telah dilakukan:

a. Motivasi dan Komitmen Organisasi perlu diperhatikan dengan baik oleh suatu instansi karena Motivasi dan Komitmen Organisasi dalam hal ini adalah sesuatu yang sangat diharapkan agar dapat meningkatkan motivasi kerja dari para pegawai sehingga mampu meningkatkan etos kerja dari para pegawai dalam melakukan pelayanan terhadap masyarakat.

b. Untuk meningkatkan motivasi tersebut diperlukan sikap kepemimpinan yang mampu untuk menjadi leader dalam suatu instansi tersebut. Oleh karena itu diharapkan bagi kepala dinas untuk mampu memotivasi bawahannya agar mampu memberikan kinerja yang terbaik dalam menjalankan amanah Negara dan pelayanan terhadap masyarakat sehingga mampu membangun citra yang baik bagi instansi.

\section{DAFTAR PUSTAKA}

Dinas Kependudukan Dan Pencatatan Sipil Kabupaten Jember. 2012. Perencanaan Dan Penyusunan Standar Pelayanan Minimal.

Direktorat Jendral Administrasi Kependudukan. 2010. Kumpulan Peraturan Menteri Dalam Negeri. Jakarta.

Direktorat Jendral Kependudukan Dan Pencatatan Sipil. 2012. Modul Bimbingan Teknis Untuk Operator Kabupaten/Kota Dan Kecamatan. Technical Operational PT. Sucofindo (Persero).

Dudokia, Muhlis. 2014. Pengaruh Disiplin Kerja Terhadap Kinerja Pegawai Kantor Dinas Kependudukan Dan Catatan Sipil Kabupaten Gorontalo Utara. 
Gitosudarmono, Indriyodan Sudita, I Nyoman. 2000. Perilaku Keorganisasian. Edisi Pertama Cetakan Kedua BPFE. Yogyakarta.

Gujarati, Danodar.1997. Ekonometrika Dasar. Jakarta: Erlangga. ..2003. Ekonometrika Dasar. Jakarta: Erlangga.

Hasibuan, S.P. Malayu.2008. Organisasi Dan Motivasi. Jakarta: Bumi Aksara.

Koesmono, H. Teman. 2005. Pengaruh Budaya Organisasi Terhadap Motivasi dan Kepuasan Kerja Serta Kinerja Pada Karyawan Subsektor Industri Pengolaham Kayu Skala menengah Di Jawa Timur. Jurusan Manajemen Dan Kewirausahaan, Vol 7. No.2, September 2005: 171-188.

Mangkunegara, Anwar Prabu. 2005. Manajemen Sumber Daya Manusia. Bandung: Remaja Rosdakarya.

Mangkuprawira. 2003. Manajemen Sumber Daya Manusia. Jakarta: Bumi Aksara.

Moleenar, Keith. 2002. Corporate Culture A Study Of Firm With Outstanding Considerat on Safety Profesional Safety. Journal Management. p.p. 18-27.

Moekijat. 1999. Pengembangan Sumber Daya Manusia. Bandung : Alfabeta.

Nasution, Budi. 2000. Manajemen Personalia. Yogyakarta: UPP AMPYKPN.

Notoatmodjo, Soekidjo. 2009. Pengembangan Sumber Daya Manusia. P.T Rineka cipta. Jakarta.

Nurjahjani Fullchi Dan Masriviastuti. 2007. Analisis Pengaruh Budaya Organisasi Terhadap Kepuasan Kerja Dan Pengaruh Pada Kinerja Karyawan (Studi Kasus Pada Lembaga Perbankan Syariah di Malang). Arthavida Journal, No.1 Februari. Hal 1-8.

Priyatno, Dwi. 2011. Lima Jam Belajar Dan Menguasai Olah Data SPSS 17. Yogyakarta: Mediakom.

Riduwan dan Kuncoro. 2007. Cara Menggunakan Dan memakai Analisis Jalur (Path Analysis). Bandung : Alfabeta.

Rivai, Veithsal Dan Sagala, Jauvani. 2009. Manajemen Sumber Daya Manusia Untuk Perusahaan. Dari Teori ke Praktik Edisi Kedua. Jakarta: Rajawali pers.

Rohman, Mawahibir . 2011. Analisis Pengaruh Kecerdasan Emosional Terhadap Komitmen Organisasi dan Kinerja Karyawan Pada PT. Adira Finance Kabupaten Lumajang. 
Robbins, Stephen P. 2002. Perilaku Organisasi. edisi Indonesia. Jakarta: PT. Prehallindo.

Santoso, Singgih. 2001. Buku Latihan SPSS Statistik Parametrik. Jakarta : PT. Gramedia.

Sarwono, Bambang. 2006. Cara Menggunakan Dan Memahami Analisis Jalur. Bandung : Alfabeta.

Sugiyono, 2002. Metodologi Penelitian Bisnis. Bandung : Alfabeta.

Suliyanto. 2005. Metodologi Penelitian. Jakarta : Bumi Aksara.

Tantowi, Arif Jauhar. 2014. Usulan Penelitian Untuk Tesis Dengan Metode Kuantitatif.

Tika, M. Pabundu. 2008. Budaya Organisasi Dan Peningkatan Kinerja Perusahaan. Cetakan Kedua. Jakarta: Bumi Aksara.

Umar, Husein. 2003. Riset Sumber Daya Manusia Dalam Organisasi. Jakarta: Gramedia Pustaka Utama.

Wibowo. 2010. Budaya Organisasi: Sebuah Kebutuhan Untuk Meningkatkan Kinerja Jangka Panjang. Cetakan Kesatu : PT. Ragrafindo Persada Jakarta. 